\title{
ABORTION POLICY AND FERTILITY OUTCOMES: THE EASTERN EUROPEAN EXPERIENCE*
}

\author{
PHILLIP B. LEVINE and DOUGLAS STAIGER \\ Wellesley College Dartmouth College
}

\begin{abstract}
Theory suggests that abortion restrictions will influence fertility outcomes such as pregnancy, abortion, and birth. This paper exploits the variations in abortion policy generated in Eastern Europe in the late 1980s and early 1990s to examine their impact on fertility outcomes. We distinguish among countries with severe, moderate, and few restrictions on abortion access and examine the impact of changes across all three categories. As we hypothesize, the results indicate that countries that changed from very restrictive to liberal abortion laws experienced a large reduction in births. Changes from modest restrictions to abortion available on request, however, led to no such change in births despite large increases in abortions, which indicates that pregnancies rose in response to more liberal abortion availability. This evidence is generally consistent with the situation that was brought about by changes in abortion access in the United States.
\end{abstract}

\section{INTRODUCTION}

$\mathrm{P}$

OLITICAL turmoil in Eastern Europe in the late 1980s and early 1990s led to a number of dramatic changes in social policy that may have had important influences on individual behavior. One set of changes involves abortion policy; over this period, a number of countries changed the extent to which abortion was restricted. Most of them removed varying degrees of restrictions that used to exist, but one country (Poland) imposed greater restrictions. Those countries in which abortion access was largely unrestricted prior to this period did not significantly alter their policies.

Although these changes had the potential to alter fertility outcomes for women, the specific behavioral implications are far from clear. If the demand curve for abortion is downward sloping and abortion restrictions can be thought of as an increase in abortion cost, then it is clear that abortions should become more common when restrictions are lifted. But the impact on births

* We would like to thank Brian Lavoie for research assistance, Jenny Hunt and Tori Velkoff for their assistance in collecting data for this project, Ann Velenchik for comments, and seminar participants at the National Bureau of Economic Research Summer Institute Children's Program Meeting, Princeton University, the University of Pennsylvania, the Harris School at the University of Chicago, Syracuse University, and Baruch College.

[Journal of Law and Economics, vol. XLVII (April 2004)]

(C) 2004 by The University of Chicago. All rights reserved. 0022-2186/2004/4701-0009\$01.50 
depends critically on the extent to which the likelihood of pregnancy changed, brought about by changes in sexual activity and contraceptive practices. If pregnancies are unaffected, then every additional abortion would result in one less birth. To the extent that pregnancies increase in response to a lower cost of abortion, however, births do not have to be perfectly negatively correlated with abortions, as some of the additional abortions may result from pregnancies that would not have occurred otherwise. In fact, births do not need to be affected at all if every additional abortion represents a pregnancy that would not have occurred otherwise. Some economic models, described briefly below, even suggest that births may rise in response to less restrictive abortion policies. As a result, the specific impact of changes in abortion policy on fertility outcomes becomes an empirical question.

This paper uses data from Eastern Europe over the past 2 decades to estimate the empirical relationship between changes in different types of abortion policies and fertility outcomes. Eastern Europe provides a valuable environment in this regard because changes in this region have been both extensive and varied. We distinguish between highly restrictive, moderately restrictive, and largely unrestrictive policies and examine the impact of changes in these policies on legal abortions, maternal deaths (as an indicator of illegal abortion), births, and pregnancies. We use quasi-experimental techniques to take advantage of this policy variation across countries and over time to estimate the effect of such changes.

The results of this analysis indicate that relaxing moderate and severe abortion restrictions has very different effects. Eliminating severe abortion restrictions significantly reduces the number of births and maternal deaths that take place within a country. On the other hand, we find no such impact associated with eliminating moderate abortion restrictions despite the significant increase in the number of abortions, which suggests that pregnancies must have risen as well. These findings are consistent with past research on the effect of abortion restrictions in the United States.

\section{TheOretical Framework}

Standard economic models of decision making can be used to analyze how changes in abortion policy influence fertility outcomes such as pregnancy, abortion, and birth rates. ${ }^{1}$ In a simple model, the fertility process can be thought of as a decision tree in which a woman chooses a level of contraceptive intensity and, if she becomes pregnant, whether or not to abort

${ }^{1}$ For examples of such models, see Gary S. Becker, A Treatise on the Family (1981); Theodore Joyce, The Impact of Induced Abortion on Black and White Birth Outcomes in the United States, 24 Demography 229 (1987); and V. Joseph Hotz \& Robert A. Miller, An Empirical Analysis of Lifecycle Fertility and Labor Supply, 56 Econometrica 91 (1988). 
or give birth. ${ }^{2}$ Within this model, less restrictive abortion policies (which can be thought of as a reduction in the cost of abortion) have two effects. One effect of lowering the cost of abortion is that a woman who is already pregnant will be more likely to have an abortion (and less likely to give birth). A second effect is that a woman will be more likely to become pregnant in the first place. The effect on pregnancy arises because lowering the cost of abortion reduces the expected cost of a pregnancy (particularly for women who think it is likely they would terminate the pregnancy), which in turn reduces the optimal level of contraceptive intensity.

This simple model has clear implications for how changes in abortion policy will influence fertility outcomes. Less restrictive abortion policies, which lower the cost of abortion, will unambiguously increase the number of pregnancies and increase the number of abortions (since more pregnancies will end in abortion). However, the impact of less restrictive abortion policies on the number of births depends on the magnitude of two offsetting effects: the increase in pregnancies and the decline in the probability that a pregnancy will result in a birth. The net impact is ambiguous, and births may even increase when abortion costs fall if the pregnancy effect is large enough.

This model also suggests that modest restrictions on abortion access may have quite different effects on fertility than when abortion is made illegal. Once pregnant, women decide whether to abort or give birth by comparing the cost of an unwanted birth with the cost of an abortion. If the cost of an unwanted birth is high for most women, then a modest increase in the cost of abortion will not have much impact on the decision to give birth once pregnant. In other words, with modest restrictions on abortion access, most women would be willing to pay the higher abortion cost and abort unwanted births if they become pregnant. But because this would increase the expected cost of a pregnancy, women would increase efforts to avoid a pregnancy. In contrast, the very large increase in abortion cost that would result if abortion were made illegal would lead many women to choose to give birth rather than abort if they happen to become pregnant. In this case, greater pregnancy avoidance may be more than offset by a rise in the probability of giving birth once pregnant, which would lead to more births. Therefore, in this simple story, we may hypothesize that outlawing abortion may result in more births, but that imposing relatively modest abortion restrictions may primarily result in fewer pregnancies rather than more births. Of course, this hypothesis rests on the assumption that the cost of an unwanted birth is high for most women, among other things. Nevertheless, it provides a reasonable framework for interpreting the analysis to follow.

On the basis of this discussion, the impact of changes in abortion policy

${ }^{2}$ See Thomas Kane \& Douglas Staiger, Teen Motherhood and Abortion Access, 111 Q. J. Econ. 467 (1996); and Phillip B. Levine \& Douglas Staiger, Abortion as Insurance (working paper, Nat'1 Bur. Econ. Res., March 2002), for models of this type. 
on fertility outcomes is an empirical question. We expect a reduction in the cost of abortion to increase the number of abortions and pregnancies but cannot determine a priori the net effect this will have on births. The remainder of the paper will inform this question by briefly reviewing prior evidence and then reporting the results of an empirical examination of Eastern European changes in abortion policy.

\section{PRIOR EVIDENCE}

An extensive empirical literature considers the response in women's behavior to changes in abortion access, most of which is based on changes in abortion access in the United States. This research has examined the impact of abortion legalization in the early 1970s separately from that of relatively minor restrictions placed on abortion access in recent years. Those studies that examine the effect of abortion legalization have focused on the impact on births since reliable data on illegal abortions (and therefore pregnancies) from the period before abortion was legalized are not available. Phillip Levine et al. employ quasi-experimental methods to the cross-state variation in the timing of abortion legalization. ${ }^{3}$ Estimates from this study indicate that abortion legalization in the United States in the early 1970s led to a reduction in births of up to 10 percent. Research from other countries similarly shows that changes in abortion legalization that took place in the 1950s and 1960s also had a dramatic impact on births, although the magnitude of these effects varies from country to country. ${ }^{4}$

Several studies have also addressed the impact of restrictions placed on abortion access in the United States since its legalization. ${ }^{5}$ This research has focused on women's responses to relatively moderate policy changes, like Medicaid funding restrictions and parental consent laws. Findings from the literature on Medicaid funding are reasonably consistent in showing that imposing the restriction leads to fewer abortions but also fewer pregnancies, which results on net in no more births or maybe even a reduction in births. ${ }^{6}$ The evidence regarding parental involvement laws is less robust across papers and model specifications, which is largely attributable to the difficulties in abstracting from travel across states and the fact that minors are such a small

${ }^{3}$ Phillip B. Levine et al., Roe v. Wade and American Fertility, 89 Am. J. Pub. Health 199 (1999).

${ }^{4}$ See Malcolm Potts et al., Abortion (1977); Stephen P. Coelen \& Robert J. McIntyre, An Econometric Model of Pronatalist and Abortion Policies, 86 J. Pol. Econ. 1077 (1978); and Tomas Frejka, Induced Abortion and Fertility: A Quarter Century of Experience in Eastern Europe, 9 Pop. \& Dev. Rev. 494 (1983).

${ }^{5}$ See Levine \& Staiger, supra note 2, for a review of this evidence.

${ }^{6}$ See Stephen Matthews et al., The Effects of Economic Conditions and Access to Reproductive Health Services on State Abortion and Birthrates, 29 Fam. Plan. Persp. 52 (1996); Phillip B. Levine et al., The Effect of Medicaid Abortion Funding Restrictions on Abortions, Pregnancies, and Births, 15 J. Health Econ. 555 (1996); and Kane \& Staiger, supra note 2. 
share of all women of childbearing age. ${ }^{7}$ Nevertheless, where evidence does exist that parental involvement laws lowered the abortion rate, there is little complementary evidence that indicates that births rose in response. Overall, this literature suggests that minor restrictions on abortion access primarily reduce both pregnancies and abortions, with little net effect on births.

One important exception in this literature is Philip Cook et al., who find that unexpected short-term limitations of Medicaid abortion funding in North Carolina were associated with a decline in abortions, a rise in births, and little change in pregnancies. ${ }^{8}$ However, unlike other studies of Medicaid funding, the reductions in Medicaid funding in North Carolina were a surprise (because of end-of-year budget shortfalls) and, therefore, unexpected at the time that women became pregnant. Thus, the North Carolina results emphasize the importance of the pregnancy decision in determining the impact of abortion availability on birth rates.

In summary, the available evidence provides several insights regarding the impact of changes in abortion access on women's fertility-related behavior. First, the effect of limits to abortion access appears to depend on the extent of the limitation. When abortion was legalized, abortion demand rose and births declined substantially. On the other hand, when modest restrictions were subsequently placed on abortion access, the bulk of the evidence indicates that abortion demand fell but that birth rates did not rise (and may have even fallen further). These facts suggest that women reduce their risk of pregnancy, through increased use of contraception or reduced sexual activity, in response to moderate abortion restrictions.

\section{NeW EVIDENCE From EASTERN EUROPE}

Recent history in Eastern Europe provides a great resource for further examination of the impact of abortion policy changes on fertility outcomes because several countries instituted dramatic changes in laws regulating abortion availability. ${ }^{9}$ This experience is particularly useful in that countries that

\footnotetext{
${ }^{7}$ See Virginia G. Cartoof \& Lorraine V. Klerman, Parental Consent for Abortion: Impact of the Massachusetts Law, 76 Am. J. Pub. Health 397 (1988); Deborah Haas-Wilson, The Impact of State Abortion Restrictions on Minor's Demand for Abortions, 31 J. Hum. Resources 140 (1996); Theodore Joyce \& Robert Kaestner, State Reproductive Policies and Adolescent Pregnancy Resolution: The Case of Parental Involvement Laws, 15 J. Health Econ. 579 (1996); and Phillip B. Levine, Parental Involvement Laws and Fertility Behavior, 22 J. Health Econ. 861 (2003).

${ }^{8}$ Philip J. Cook et al., The Effects of Short-Term Variation in Abortion Funding on Pregnancy Outcomes, 18 J. Health Econ. 241 (1999).

${ }^{9} \mathrm{~A}$ handful of changes in abortion policies in Western Europe also took place over the past 2 decades. In particular, the Netherlands (1981), Greece (1985), and Belgium (1991) made abortion available on request when it had been officially severely restricted in the past (although enforcement activity was minimal and abortion was apparently practiced openly). Portugal (1984) and Spain (1985) eased access slightly from laws that had been very restrictive. The former Federal Republic of Germany (1993) made abortion available on request when moderate restrictions used to be imposed. Unfortunately, no reliable abortion data exist in those countries
} 
imposed restrictions strongly enforced them and liberalization was clearly brought about by political change. This section of the paper will present an empirical analysis of the impact of those changes and will focus on the 198097 period.

\section{A. Description of Abortion Laws}

Eastern European countries have had in place a wide variety of laws regarding abortion access in the recent past, ranging from countries like Romania prior to 1990 , where abortion was virtually completely outlawed, to countries like Russia, where abortion was available on request with few, if any, barriers throughout the period. Table 1 presents a brief summary of laws in each country, noting the changes that have taken place since 1980. The Appendix provides a list of the sources we used to compile this table. Here and in the remainder of the analysis throughout the period we consider the former German Democratic Republic as well as the Czech and Slovak republics as separate countries. ${ }^{10}$

We provide a main classification of the legal status of abortion in each country at a point in time and break it into three separate categories. ${ }^{11}$ These categories include (1) "life/medical," in which abortion is available only to save the life of the mother or only to those with specific, narrow medical conditions; (2) "medical/social," in which an abortion is available to those with medical problems, including mental health problems, or those for whom the birth of a child would present some hardship; and (3) "on request," in which an abortion is available if a woman asks for one. ${ }^{12}$ We include a set of classifications that describe additional regulations regarding abortion access among those countries/years in which abortion is generally available (that is, either medical/social or on request). These include whether there is

that had strongly restricted abortion access, which makes it impossible to estimate the impact of changes in these laws on abortions and pregnancies.

${ }^{10}$ We have chosen not to include the new countries that emerged from the former Yugoslavia, partly because of limited data availability and partly because of the conditions of war that persisted over much of this region in the 1990s.

${ }^{11}$ These classifications largely follow those used by the Alan Guttmacher Institute in its summary of world abortion laws as described in Stanley K. Henshaw, Induced Abortion: A World Review, 1990, 22 Fam. Plan. Persp. 76 (1990); and Anika Rahman, Laura Katzive, \& Stanley K. Henshaw, A Global Review of Laws on Induced Abortion, 1985-1997, 24 Int'1 Fam. Plan. Persp. 56 (1998). It is important to note that abortion access can vary greatly even within a category. For instance, in Russia, a woman seeking an abortion faces virtually no obstacles in obtaining one. In the former German Democratic Republic after 1993 abortion is also available on request, but a woman seeking an abortion is required to be counseled toward giving birth and must wait 3 days before the procedure can be performed. Nevertheless, if she persists in her request to obtain an abortion, she can get one, which is why we code this country as "on request."

${ }^{12}$ We do not separately categorize those countries with restrictive policies in which abortion is available in cases of rape/incest or fetal defects, but these exceptions are noted in the brief narrative description for each country. 
TABLE 1

Abortion Policies in Eastern Europe and Former Soviet Republics, 1980-97

\begin{tabular}{|c|c|c|c|c|c|c|}
\hline Country & $\begin{array}{c}\text { Years } \\
\text { Legalized }\end{array}$ & Description & $\begin{array}{l}\text { Legal Status } \\
\text { of Abortion }\end{array}$ & $\begin{array}{l}\text { Waiting Period/ } \\
\text { Counseling }\end{array}$ & $\begin{array}{c}\text { Large } \\
\text { Cost } \\
\text { Subsidy }\end{array}$ & $\begin{array}{l}\text { Parental } \\
\text { Consent }\end{array}$ \\
\hline \multicolumn{7}{|l|}{ Eastern Europe: } \\
\hline \multirow[t]{2}{*}{ Albania } & Before 1991 & Legal for limited medical reasons only & Life/medical & NA & NA & NA \\
\hline & 1991-Present & Legal on request in first 12 weeks of pregnancy & On request & $\mathrm{N}$ & $\mathrm{Y}$ & $\mathrm{N}$ \\
\hline \multirow[t]{2}{*}{ Bulgaria } & 1973-89 & $\begin{array}{l}\text { Legal for medical reasons or on request in the first } 10 \text { weeks of pregnancy for } \\
\text { certain categories of women, like those with two or more children }\end{array}$ & Medical/social & $\mathrm{Y}$ & $\mathrm{Y}$ & $\mathrm{N}$ \\
\hline & 1990-Present & Legal on request in the first 12 weeks of pregnancy & On request & $\mathrm{N}$ & $\mathrm{Y}$ & $\mathrm{N}$ \\
\hline \multirow{2}{*}{ Czech republic } & $1957-86$ & Legal for maternal health or social reasons in the first 12 weeks of pregnancy & Medical/social & $\mathrm{Y}$ & $\mathrm{Y}$ & $\mathrm{N}$ \\
\hline & 1987-Present & Legal in the first 12 weeks of pregnancy on request and physician approval & On request & $\mathrm{N}$ & $\mathrm{Y}$ & $\mathrm{Y}$ \\
\hline \multirow[t]{2}{*}{ Germany (former GDR) } & $1972-92$ & Legal on request in the first 12 weeks of pregnancy & On request & $\mathrm{N}$ & $\mathrm{Y}$ & $\mathrm{N}$ \\
\hline & 1993-Present & $\begin{array}{l}\text { Legal in the first } 12 \text { weeks of pregnancy after mandatory counseling and a 3-day } \\
\text { waiting period; procedure is subsidized in majority of cases }\end{array}$ & On request & $\mathrm{Y}$ & $\mathrm{Y}$ & $\mathrm{N}$ \\
\hline \multirow[t]{2}{*}{ Hungary } & 1973-92 & $\begin{array}{l}\text { Legal for medical reasons or on request in the first } 12 \text { weeks of pregnancy for } \\
\text { certain categories of women, like those with three or more children }\end{array}$ & Medical/social & $\mathrm{Y}$ & $\mathrm{Y}$ & $\mathrm{N}$ \\
\hline & 1993-Present & $\begin{array}{l}\text { Legal in the first } 12 \text { weeks of pregnancy after counseling and a 3-day waiting } \\
\text { period }\end{array}$ & On request & $\mathrm{Y}$ & $\mathrm{Y}$ & $\mathrm{Y}$ \\
\hline \multirow[t]{2}{*}{ Poland } & 1956-92 & Legal in the first 12 weeks of pregnancy for medical and social reasons & Medical/social & $\mathrm{Y}$ & $\mathrm{Y}$ & $\mathrm{Y}$ \\
\hline & 1993-Present & $\begin{array}{l}\text { Legal only when the pregnancy threatens the mother's life or health or in cases of } \\
\text { rape/incest or fetal defects }\end{array}$ & Life/medical & NA & NA & NA \\
\hline \multirow[t]{2}{*}{ Romania } & $1966-89$ & $\begin{array}{l}\text { Legal in very limited circumstances (mother's life, rape, very large family, and the } \\
\text { like) }\end{array}$ & Life/medical & NA & NA & NA \\
\hline & 1990-Present & Legal on request in the first 12 weeks of pregnancy & On request & $\mathrm{N}$ & $\mathrm{Y}$ & $\mathrm{N}$ \\
\hline \multirow{2}{*}{ Slovak republic } & $1957-86$ & Legal for maternal health or social reasons in the first 12 weeks of pregnancy & Medical/social & $\mathrm{Y}$ & $\mathrm{Y}$ & $\mathrm{N}$ \\
\hline & 1987-Pres & Legal in the first 12 weeks of pregnancy on request and physician approval & On request & $\mathrm{N}$ & $\mathrm{Y}$ & $\mathrm{Y}$ \\
\hline Former Soviet republics ${ }^{\mathrm{a}}$ & 1955-Present & $\begin{array}{l}\text { Legal on request in the first } 12 \text { weeks of pregnancy following consultation with } \\
\text { doctor and notification of possible adverse consequences }\end{array}$ & On request & $\mathrm{Y}$ & $\mathrm{Y}$ & $\mathrm{N}$ \\
\hline
\end{tabular}

Belarus, Estonia, Latvia, Lithuania, Moldova, Russian Federation, and Ukraine. 
a waiting period and/or counseling before an abortion may be performed, whether the procedure is subsidized by the government, and whether parental consent is required for minors.

Over the 18-year period we examine, a number of changes in the primary legal status of abortion are observed in these countries. Most Eastern European countries that were not part of the former Soviet Union instituted fundamental changes to their laws governing abortion. Some, but not all, of these changes (Albania in 1991, Bulgaria in 1990, and Romania in 1990) coincided with the transition from communism to democracy as strong pronatalist policies previously enacted in these countries were abandoned. In the Czech and Slovak republics, requirements that an abortion request be approved on the basis of a medical or social condition were dropped in 1987, and abortion became available on request. This change took place 6 years before the two republics split apart and 3 years before the collapse of the Soviet Union. Hungary made a similar change in policy in 1993 . The only example in all of Europe of a significant tightening of abortion availability during this period is Poland. After Soviet domination ended, the strong influence of the Catholic Church led to the imposition of strict regulations in 1993, which allowed abortion only in limited circumstances. In the European republics of the former Soviet Union, abortion was available on request both before and after the breakup.

\section{B. Methodology and Data}

To examine the impact of changes in abortion policy on fertility-related behavior, we estimated regression models of each outcome considered as a function of the legal status of abortion, macroeconomic conditions, specific age composition among all women of childbearing age, country and year fixed effects, and, in some models, country-specific trends. The outcomes we consider are the abortion rate (abortions per 1,000 women aged 15-44), the rate of deaths to women of childbearing age relative to that for men (the ratio of the number of deaths per 100,000 women in this age group to the comparable statistic for men), birth rates, and the "pregnancy rate" (the sum of births and abortions per 1,000 women aged 15-44).

Models of the abortion rate are estimated to provide an indication that abortion access is, in fact, changing when its legal status changes. We consider the relative female death rate to provide an indication of the extent of illegal abortions performed in a country. If a pregnant woman has a strong preference against giving birth and a legal abortion is not available, she may turn to an illegal abortion, which may pose a health risk to the mother. Following William Dow and Nick Ronan, we normalize the rate of death to women of childbearing age by using the analogous measure for men to control for other 
possible changes taking place over time in the health care delivery system of each country. ${ }^{13}$

We control for macroeconomic conditions in these models as well because they may also influence our outcome measures and be related to the timing of changes in abortion law. Particularly in Eastern Europe and the former republics of the Soviet Union, the decline and collapse of the Soviet empire led to dramatic economic contractions and rampant inflation in many countries. To the extent that these economic developments are correlated with the political developments that led to changes in abortion policy, it is important to control for them. Therefore, our models include measures of gross domestic product per capita and the level of inflation.

In the model, country fixed effects are included to control for long-term, country-specific differences in outcomes that may be attributed to differences in history, culture, other institutional arrangements, and the like. Time fixed effects are added to control for trends occurring over time that are common to each country. For instance, the timing of the decline and fall of the Soviet empire certainly had important influences on all these countries. In some specifications, we also include time trends that are allowed to vary across countries. This approach provides the advantage of capturing any factor within a country that is changing over time and is also different from that occurring in other countries. On the other hand, some worry that such models result in "overfitting" the data, which significantly reduces the power of the analysis. ${ }^{14}$ We present our results both with and without these trends to examine the sensitivity to their inclusion. In models without country-specific trends, identification is provided by those countries that changed their abortion laws over the period. In models with the trends, identification is based on the discrete nature of the change in abortion laws and the change in outcomes right around the time of the change of the abortion laws.

The models that we estimate assume that the policy changes introduced were exogenous to the differences across countries in contemporaneous social problems that may also have been related to changes in fertility outcomes. Yet social problems were clearly present in this region, and perhaps in some countries more than others, over the time period considered here as huge structural economic adjustments affected multiple dimensions of everyday life. Economic difficulties may have provided at least part of the impetus to countries with restrictive abortion policies to change them in response to the demand for smaller families and greater fertility control. If so, our quasi-

\footnotetext{
${ }^{13}$ William H. Dow \& Nick Ronan, Maternal Mortality Effects of Abortion Legalization (Working paper, Rand, March 1997).

${ }^{14}$ See Rebecca M. Blank, What Causes Public Assistance Caseloads to Grow? 36 J. Hum. Resources 85 (2001).
} 
experimental methods will provide an inaccurate causal interpretation of the impact of these changes. ${ }^{15}$

We believe, however, that this potential problem does not seriously interfere with a causal interpretation of our findings. First, economic conditions were weak throughout much of this period in all of these countries so changes in the demand for abortions and births may partly be captured by year fixed effects and even more so in models that control for country-specific trends. Second, the timing of changes in abortion policy does offer some variation in policies across countries that are not directly linked to the period of the most dramatic social upheaval. Nevertheless, this potential limitation of our methodology needs to be kept in mind in interpreting the results of our analysis.

To estimate these models, we have compiled a data set comprised of abortions, births, deaths by sex and age, and population size by sex and age for countries in Eastern Europe and the former Soviet republics in Europe. Data on each outcome are available for each country except Albania in most, but not all, years in our sample period of 1980-97. Our data sources are presented in the Appendix. Briefly, we obtained the majority of our data from various international compilations from the United Nations, the World Health Organization, and the Council of Europe. ${ }^{16}$ It is important to recognize that reporting problems often lead to counts of abortion data that are understated. In our analysis of abortion rates (as well as pregnancy rates), we will separately estimate models using all available data as well as for those countries that have been determined by the Alan Guttmacher Institute to have virtually complete abortion counts. ${ }^{17}$ These countries include Belarus, Bulgaria, the Czech Republic, Estonia, Hungary, Latvia, and the Slovak republic.

In addition to these demographic data, we have also collected information on macroeconomic conditions in each of the countries in our analysis. The specific measures we include are the natural log of per capita gross domestic product (GDP) and a set of dummy variables representing different levels of inflation (less than 5 percent, between 5 and 25 percent, between 25 and 100 percent, and greater than 100 percent). Following the collapse of the

${ }^{15}$ See Timothy Besley \& Anne Case, Unnatural Experiments? Estimating the Incidence of Endogenous Policies, 110 Econ J. F672 (2000).

${ }^{16}$ The main complications arose in the former German Democratic Republic and the Czech and Slovak republics because of German reunification and the breakup of Czechoslovakia in the middle of our sample period. To acquire data for the eastern region of Germany following reunification and for the two Czechoslovak republics prior to their separation required additional data from the united countries' statistical yearbooks and direct communications with their national statistical offices.

${ }^{17}$ Another potential problem with the available abortion data is that in the former Soviet republics through the late 1980s, abortion counts included spontaneous abortions. We do not believe that this presents a serious limitation for our analysis for two reasons. First, most spontaneous abortions occur relatively soon after the start of the pregnancy, and it would seem unlikely that the majority of them would be counted. Second, no noticeable deviation from trend is apparent in these republics at the time of the change in definitions. 
Soviet empire, these data were largely available from the World Bank. ${ }^{18}$ But during the communist era, the available macroeconomic data were obtained from estimates made by the Central Intelligence Agency (CIA), for which the quality is unknown. ${ }^{19}$

\section{Descriptive Analysis}

Before presenting the results of our regression analysis, we first present a descriptive analysis that is intended to characterize the data and to highlight some of the econometric issues that will arise subsequently. We begin by reporting Table 2, which presents mean values of our outcome measures in Eastern Europe and the republics of the former Soviet Union weighted by the relevant population measure in each country in 1980 and $1995 .{ }^{20}$ We also report statistics for Western Europe and the United States for purposes of comparison.

The first row of the table provides estimates of the reported abortion rate and evidence of huge disparities across regions. In 1980, about 13 women per 1,000 of childbearing age aborted in Western Europe, but in Eastern Europe the comparable level was more than three times greater, and in the European republics of the former Soviet Union, the level was about 10 times greater. Those relative comparisons do not change much by 1995 in that all regions experienced at least a 25 percent reduction in abortion rates, and the former Soviet republics still exhibit an abortion rate 8 times greater than that in Western Europe. But that masks the absolute magnitude of the decline in the Soviet Union, which declined from a level of 127.4 to 75.9.

Regarding female mortality, we see that across the age spectrum and across regions women in these age ranges experience levels of mortality that are one-quarter to one-half those of men. This excessive risk of death among men is particularly apparent in the former Soviet republics. These ratios have

\footnotetext{
${ }^{18}$ The former German Democratic Republic and the former Czechoslovakia present additional problems since macroeconomic data are difficult to obtain for separate regions within a country. For Germany, we were able to obtain separate estimates for the eastern regions of the level of GDP starting in 1991. For previous years, we calculated the level of GDP using the more recent data combined with CIA estimates of GDP growth rates in earlier years. We also have inflation data from the German Statistical Office beginning in 1992 and CIA estimates through 1989, but we were unable to locate data for 1990 and 1991. For the Czech and Slovak republics, the World Bank reports separate GDP data going back to 1984. Before that, we assigned the GDP growth rates from the combined Czechoslavakia to the 1984 levels of GDP to project backward. We also assumed that inflation rates in the two halves of the country were the same before they separated.

${ }^{19}$ Even using the CIA estimates, some countries and years still have missing data for these macroeconomic variables. To include these countries in our analysis, we have added dummy variables for both the GDP and inflation measures indicating whether or not these data are missing.

${ }^{20}$ The latter year was chosen because the problem of missing data becomes somewhat greater for 1996 and 1997.
} 
TABLE 2

Weighted Average Values of Outcome Measures, by Region

\begin{tabular}{|c|c|c|c|c|c|c|c|c|}
\hline & \multicolumn{2}{|c|}{$\begin{array}{l}\text { EASTERN } \\
\text { EUROPE }\end{array}$} & \multicolumn{2}{|c|}{$\begin{array}{l}\text { Former Soviet } \\
\text { RePUblics }\end{array}$} & \multicolumn{2}{|c|}{$\begin{array}{l}\text { WESTERN } \\
\text { EUROPE }\end{array}$} & \multicolumn{2}{|c|}{ United States } \\
\hline & 1980 & 1995 & 1980 & 1995 & 1980 & 1995 & 1980 & 1995 \\
\hline Reported abortion rate & 41.7 & 32.4 & 127.4 & 75.9 & 12.9 & 9.6 & 29.3 & 22.9 \\
\hline \multicolumn{9}{|l|}{$\begin{array}{l}\text { Relative female } \\
\text { death rate: }\end{array}$} \\
\hline Aged $15-44$ & .418 & .356 & .273 & .264 & .463 & .436 & .423 & .413 \\
\hline Aged $15-19$ & .421 & .427 & .336 & .354 & .392 & .390 & .376 & .382 \\
\hline Aged 20-34 & .385 & .334 & .240 & .237 & .418 & .376 & .356 & .363 \\
\hline Aged $35-44$ & .436 & .354 & .283 & .266 & .522 & .498 & .532 & .451 \\
\hline Total fertility & & & & & & & & \\
\hline rate & 2.22 & 1.36 & 1.93 & 1.36 & 1.79 & 1.47 & 1.84 & 2.02 \\
\hline \multicolumn{9}{|l|}{$\begin{array}{l}\text { Birth rate, by age } \\
\text { of woman: }\end{array}$} \\
\hline Aged $15-44$ & 79.5 & 45.4 & 68.9 & 42.1 & 60.7 & 51.2 & 68.4 & 65.5 \\
\hline Aged $15-19$ & 43.8 & 31.2 & 50.1 & 47.0 & 20.5 & 12.0 & 53.0 & 56.8 \\
\hline Aged 20-34 & 123.3 & 82.2 & 111.6 & 68.6 & 101.4 & 82.0 & 98.3 & 100.3 \\
\hline Aged 35-44 & 14.6 & 10.1 & 11.4 & 6.6 & 16.6 & 21.1 & 12.5 & 21.1 \\
\hline \multicolumn{9}{|l|}{ Pregnancy rate, women } \\
\hline aged $15-44$ & 121.2 & 77.8 & 196.7 & 118.0 & 69.7 & 59.1 & 97.7 & 88.4 \\
\hline
\end{tabular}

NotE. - The relative female death rate for women aged 15-44 is the ratio of the female death rate to the male death rate for men and women in that age group. Reported statistics are weighted by the relevant denominator for each rate (for example, the number of women between the ages of 15 and 44 for the total fertility rate). Countries from the former U.S.S.R. include Belarus, Latvia, Lithuania, the Republic of Moldova, the Russian Federation, and the Ukraine. The pregnancy rate is defined to be the sum of the total number of births and abortions per 1,000 women aged 15-44. The abortion rate and birth rate for women aged 15-44 do not sum to the pregnancy rate because of missing data on abortions.

fallen over time, most notably in Eastern Europe and somewhat in Western Europe among nonteens.

Perhaps the most notable change over time in these data is the dramatic decline in births in all of Europe (but not in the United States). The total fertility rate, which represents the number of children a woman can expect to have over all her childbearing years on the basis on present age-specific birth rates, stood at roughly 2 (or replacement level) in all regions of Europe in 1980. By 1995, that rate was below 1.5 in all regions. In fact, in the former German Democratic Republic (East Germany), the level has fallen below unity and has remained there since 1991. With declining rates of abortion and birth, our constructed pregnancy rate declines as well. The striking statistic here is that almost two-thirds of these constructed pregnancies are represented by abortions in the former republics of the Soviet Union.

Figure 1 presents the complete time series in total fertility rates over our sample period for Eastern Europe, the former Soviet republics, and Western European countries for comparison. It shows a slow gradual downward trend in Western Europe but a dramatic decline beginning in 1988 or 1989 in Eastern Europe. Although total fertility rates began somewhat higher in these 


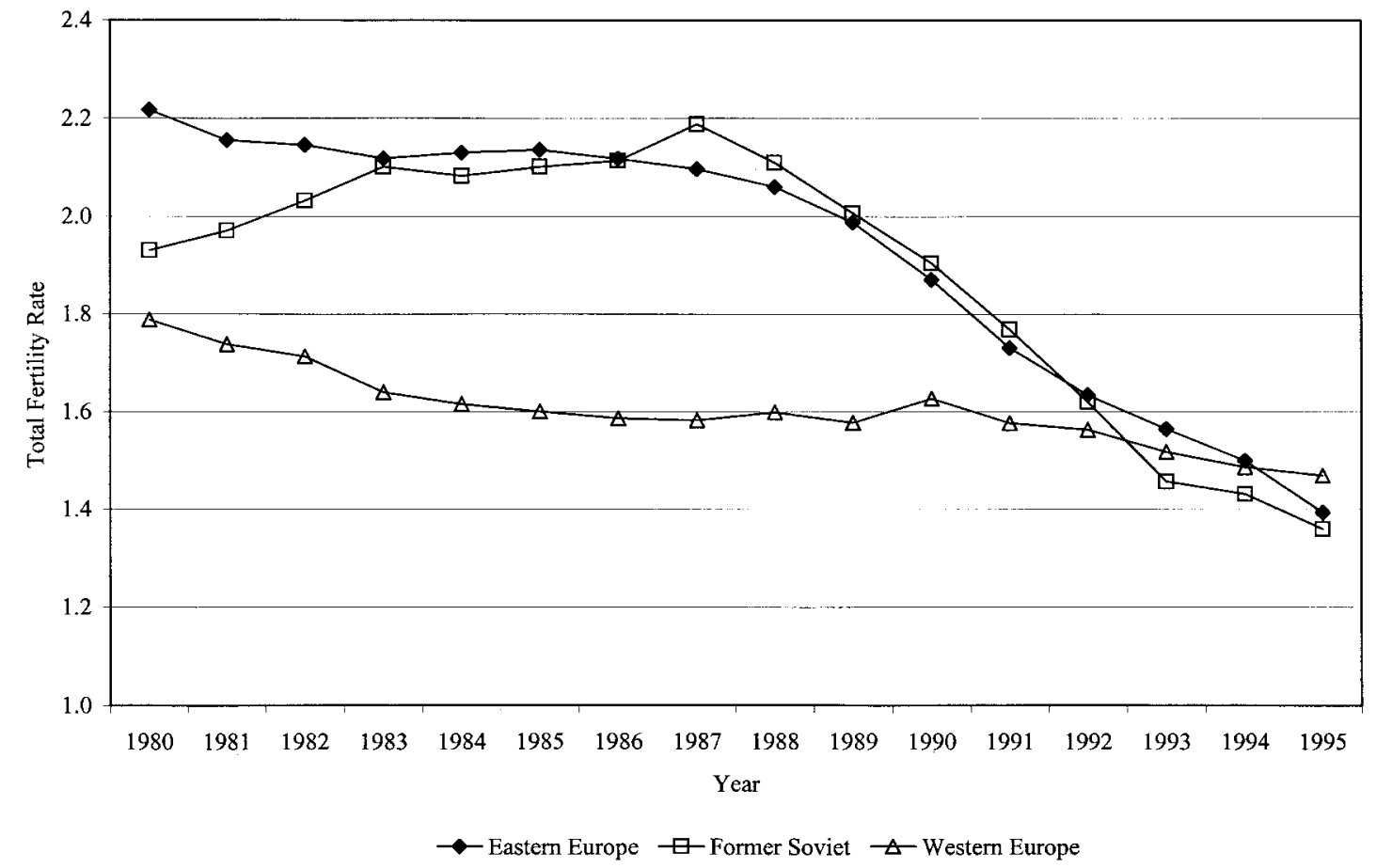

FIGURE 1.-Total fertility rates in Europe 
eastern regions compared with Western Europe, by 1993 this was reversed. The timing of this decline corresponds well with the political and economic uncertainties brought about by the decline and dissolution of the Soviet Union. This figure illustrates the importance of including year fixed effects in our econometric analysis.

\section{Econometric Results}

Table 3 reports the results of our econometric analysis. ${ }^{21}$ For each outcome, odd-numbered columns do not include state-specific trends, and evennumbered columns do include them. In all specifications, the omitted legal status is available on request, so all coefficients for those types of abortion laws included should be interpreted relative to an on-request legal regime. We have omitted this type of policy rather than the other extreme because no country with severe restrictions has complete abortion (and therefore pregnancy) data. In these specifications, the results are interpreted as the impact of imposing moderate or severe restrictions relative to having more liberal abortion policies in place. Since most countries changed their policies in the opposite direction, the impact of these policy changes would then be the negative of the values reported in this table.

\section{The Abortion Rate}

The first four columns of this table display our estimates for models of the abortion rate and differentiate between estimates from models using all available abortion data and estimates from models only using those countries whose abortion data is considered to be of high quality. The results provide strong evidence that the status of abortion laws has a large impact on the abortion rate. For instance, on the basis of all available abortion data, countries in which abortion is legal only to save the mother's life or for specific medical reasons have abortion rates that are only about 5 percent of the level observed in countries in which abortion is legal on request. ${ }^{22}$ Unfortunately, we cannot identify this parameter in models with the more limited, complete abortion data.

Those countries/years in which abortion is available for medical and social

\footnotetext{
${ }^{21}$ In all specifications, reported standard errors are corrected for heteroskedasticity and an arbitrary covariance structure between time periods within countries, as suggested by Marianne Bertrand, Esther Duflo, \& Sendhil Mullainathan, How Much Should We Trust Difference-inDifference Estimates? (Working paper, Cambridge: Massachusetts Inst. Tech., Dep't Econ., October 2001)

${ }^{22}$ With the dependent variable measured in logs and parameter estimates this large in absolute value, one cannot simply interpret the coefficients as an approximation of a percentage change. The impact is obtained by taking the number $E$ raised to the power of the coefficient (that is, $E^{-3.1}=.045$, so countries where abortion is available only to save the mother's life or for specific medical reasons have abortion rates that are 4.5 percent the level observed in countries and years where abortion is available on demand).
} 
TABLE 3

Effect of Legal Status of Abortion in Eastern Europe

\begin{tabular}{|c|c|c|c|c|c|c|c|c|c|c|c|c|}
\hline & \multicolumn{4}{|c|}{ ABORTION RATE } & \multirow{2}{*}{\multicolumn{2}{|c|}{$\begin{array}{l}\text { Relative Female } \\
\text { Death Rate } \\
(N=215) \\
\end{array}$}} & \multirow{2}{*}{\multicolumn{2}{|c|}{$\begin{array}{l}\text { BIRTH RATE } \\
(N=231)\end{array}$}} & \multicolumn{4}{|c|}{ Pregnancy Rate } \\
\hline & \multicolumn{2}{|c|}{$\begin{array}{l}\text { All Data } \\
(N=223)\end{array}$} & \multicolumn{2}{|c|}{$\begin{array}{l}\text { Complete Data } \\
(N=115)\end{array}$} & & & & & \multicolumn{2}{|c|}{$\begin{array}{l}\text { All Data } \\
(N=213) \\
\end{array}$} & \multicolumn{2}{|c|}{$\begin{array}{l}\text { Complete Data } \\
(N=109)\end{array}$} \\
\hline & (1) & (2) & (3) & (4) & (5) & (6) & (7) & (8) & (9) & (10) & (11) & (12) \\
\hline $\begin{array}{l}\text { Legal to save the mother's life or for } \\
\text { other specific medical reasons }\end{array}$ & $\begin{array}{r}-3.114 \\
(.692)\end{array}$ & $\begin{array}{r}-2.596 \\
(.300)\end{array}$ & & & $\begin{array}{l}.100 \\
(.023)\end{array}$ & $\begin{array}{c}.028 \\
(.031)\end{array}$ & $\begin{array}{c}.174 \\
(.028)\end{array}$ & $\begin{array}{c}.093 \\
(.072)\end{array}$ & $\begin{array}{c}-.274 \\
(.118)\end{array}$ & $\begin{array}{c}-.450 \\
(.225)\end{array}$ & & \\
\hline Legal for medical or social reasons & $\begin{array}{c}-.624 \\
(.293)\end{array}$ & $\begin{array}{c}-.196 \\
(.190)\end{array}$ & $\begin{array}{c}-.284 \\
(.046)\end{array}$ & $\begin{array}{c}-.249 \\
(.057)\end{array}$ & $\begin{array}{c}-.038 \\
(.028)\end{array}$ & $\begin{array}{c}-.015 \\
(.020)\end{array}$ & $\begin{array}{c}.011 \\
(.038)\end{array}$ & $\begin{array}{c}.039 \\
(.035)\end{array}$ & $\begin{array}{c}-.239 \\
(.114)\end{array}$ & $\begin{array}{c}-.276 \\
(.138)\end{array}$ & $\begin{array}{c}-.106 \\
(.015)\end{array}$ & $\begin{array}{c}-.081 \\
(.022)\end{array}$ \\
\hline Log GDP per capita & $\begin{array}{c}-.463 \\
(.222)\end{array}$ & $\begin{array}{c}-.400 \\
(.176)\end{array}$ & $\begin{array}{c}-.175 \\
(.132)\end{array}$ & $\begin{array}{c}-.431 \\
(.381)\end{array}$ & $\begin{array}{c}-.120 \\
(.045)\end{array}$ & $\begin{array}{c}-.013 \\
(.100)\end{array}$ & $\begin{array}{r}-.239 \\
(.038)\end{array}$ & $\begin{array}{c}-.052 \\
(.078)\end{array}$ & $\begin{array}{c}-.234 \\
(.039)\end{array}$ & $\begin{array}{l}.050 \\
(.088)\end{array}$ & $\begin{array}{l}.082 \\
(.133)\end{array}$ & $\begin{array}{c}-.263 \\
(.143)\end{array}$ \\
\hline Inflation between $5 \%$ and $25 \%$ & $\begin{array}{c}.174 \\
(.086)\end{array}$ & $\begin{array}{c}.033 \\
(.048)\end{array}$ & $\begin{array}{c}-.038 \\
(.015)\end{array}$ & $\begin{array}{c}-.014 \\
(.026)\end{array}$ & $\begin{array}{l}.009 \\
(.016)\end{array}$ & $\begin{array}{c}-.005 \\
(.010)\end{array}$ & $\begin{array}{c}-.002 \\
(.017)\end{array}$ & $\begin{array}{c}-.021 \\
(.016)\end{array}$ & $\begin{array}{c}.048 \\
(.020)\end{array}$ & $\begin{array}{c}.026 \\
(.019)\end{array}$ & $\begin{array}{c}-.042 \\
(.026)\end{array}$ & $\begin{array}{r}-.016 \\
(.011)\end{array}$ \\
\hline Inflation between $25 \%$ and $100 \%$ & $\begin{array}{l}.160 \\
(.083)\end{array}$ & $\begin{array}{c}.252 \\
(.101)\end{array}$ & $\begin{array}{c}.078 \\
(.038)\end{array}$ & $\begin{array}{l}.098 \\
(.049)\end{array}$ & $\begin{array}{c}-.002 \\
(.024)\end{array}$ & $\begin{array}{c}-.009 \\
(.017)\end{array}$ & $\begin{array}{l}.016 \\
(.055)\end{array}$ & $\begin{array}{c}-.012 \\
(.030)\end{array}$ & $\begin{array}{c}.099 \\
(.060)\end{array}$ & $\begin{array}{l}.052 \\
(.032)\end{array}$ & $\begin{array}{l}.016 \\
(.036)\end{array}$ & $\begin{array}{l}.030 \\
(.029)\end{array}$ \\
\hline Inflation $>100 \%$ & $\begin{array}{c}.395 \\
(.096)\end{array}$ & $\begin{array}{c}.342 \\
(.080)\end{array}$ & $\begin{array}{c}.067 \\
(.035)\end{array}$ & $\begin{array}{c}.075 \\
(.074)\end{array}$ & $\begin{array}{c}.012 \\
(.018)\end{array}$ & $\begin{array}{c}-.008 \\
(.011)\end{array}$ & $\begin{array}{c}.004 \\
(.058)\end{array}$ & $\begin{array}{c}-.024 \\
(.036)\end{array}$ & $\begin{array}{c}.091 \\
(.057)\end{array}$ & $\begin{array}{c}.033 \\
(.032)\end{array}$ & $\begin{array}{c}.019 \\
(.034)\end{array}$ & $\begin{array}{c}.014 \\
(.046)\end{array}$ \\
\hline Country-specific trend & $\mathrm{N}$ & $\mathrm{Y}$ & $\mathrm{N}$ & $\mathrm{Y}$ & $\mathrm{N}$ & $\mathrm{Y}$ & $\mathrm{N}$ & $\mathrm{Y}$ & $\mathrm{N}$ & $\mathrm{Y}$ & $\mathrm{N}$ & $\mathrm{Y}$ \\
\hline
\end{tabular}

Note. - The dependent variables in all models are measured in logs. All estimates are obtained from models that include country and year fixed effects and dummy variables indicating whether GDP and inflation data are missing and the percentage of women between the ages of 15 and 44 in each 5-year age interval; the models are weighted by the size of the relevant population. Reported standard errors are corrected for heteroskedasticity and an arbitrary covariance structure between time periods within countries. 
reasons are also found to have a significantly lower abortion rate compared with those countries/years in which abortion is available on request. In particular, when we only use those countries with complete abortion data (columns 3 and 4), we find a robust estimate of about a 25 percent reduction in the abortion rate when these moderate restrictions are imposed.

\section{Relative Female Death Rates}

Columns 5 and 6 present estimates from models where the dependent variable is the $\log$ of the ratio of female-to-male death rates for those aged 15-44. In the model without country-specific trends, estimates indicate that the relative female death rate is 10 percent higher in countries where abortion is available only to save a mother's life or for other specific medical reasons compared with countries in which abortion is available on request. The introduction of country-specific trends, however, lowers this estimate and increases its standard error to the point where it is no longer statistically significant. The ambiguity in these findings makes it difficult to draw strong conclusions regarding the impact of strong abortion restrictions on maternal deaths and, hence, illegal abortion. On the other hand, we find no evidence that countries with weaker abortion restrictions (namely, those where abortion is available for medical or social reasons) experience any difference in relative female death rates. Point estimates are wrong signed and statistically insignificant. This finding is important because it provides evidence that illegal abortion is probably not a tremendous problem in countries with these weaker restrictions compared with those in which abortion is available on request. It still may take place, but it seems unlikely that it is extensive or terribly risky. This conclusion will play an important role in our subsequent analysis of pregnancy behavior.

\section{3. $\quad$ Birth Rates}

Estimates from our analysis of the responsiveness of fertility to changes in abortion policy are reported in columns 7 and $8 .{ }^{23}$ Restrictive abortion laws in which abortion is available only to save the mother's life or for other specific medical reasons increase the birth rate by $9-17$ percent relative to that in a regime where abortion is available on request. This finding is statistically significant in the model without country-specific trends, but with these trends, imprecision in the estimate would lead us to fail to reject the null hypothesis despite a very large point estimate. One could infer from

\footnotetext{
${ }^{23}$ We have also estimated analogous models where the dependent variable is the total fertility rate. The results from these models were very similar to those reported here. This makes sense because the main difference between this birth rate and the total fertility rate is the specific age composition of women of childbearing age. But these models control for age composition. We chose to report models of the birth rate because they are easier to interpret in the context of an analysis of abortion and pregnancy behavior.
} 
these findings that legalizing abortion is likely to result in a significant drop in the birth rate, as greater abortion access eliminates unwanted births.

On the other hand, we see that restricting abortion so that it is available only for medical or social reasons had relatively little impact on births. Point estimates here are relatively small and are not statistically significant. On the basis of our earlier evidence that indicates that these policies did have a rather large impact on abortion rates, the combination of these findings suggests that pregnancy rates are lower in this policy environment compared with one where abortion is available on request.

\section{Pregnancies}

Estimates from models of the pregnancy rate (or the sum of abortions and births per 1,000 women aged 15-44) are reported in columns 9-12. With the use of all the available abortion data (columns 9 and 10), estimates indicate that pregnancy rates fall by 27 to 45 percent when abortion moves from available on request to available only in serious medical circumstances. This estimate may be inaccurate, however, in that it fails to include counts of pregnancies that result in illegal abortions when restrictions are severe. The results from columns 5 and 6 provide some evidence for this in that maternal mortality rates rise when abortion is severely restricted (in the model without country-specific trends), which indicates that at least some illegal abortions are performed. This problem is identical to the one described earlier regarding the impact of abortion legalization on pregnancy rates in the United States. Without additional information, we cannot draw strong conclusions regarding the pregnancy impact of such a policy change.

On the other hand, we are on safer ground drawing strong conclusions regarding the impact of more moderate abortion restrictions. In columns 5 and 6 , we found no evidence that maternal mortality rises when abortion is made available for medical or social reasons compared with when it is available on request. This suggests that illegal abortions are probably not a huge problem under these circumstances. We do not conclude from this that they do not occur, only that they are not that prevalent.

This is important because we also see that the pregnancy rate is estimated to fall by about 25 percent in response to these more moderate restrictions when we use all available abortion data and by roughly 10 percent when we restrict the analysis to those countries with complete abortion data. If illegal abortions are performed only infrequently in locations that have imposed these more moderate restrictions, then these estimates probably are at least close approximations of the true pregnancy effect. On the basis of this evidence, we conclude that pregnancies are meaningfully reduced when moderate abortion restrictions are imposed. 


\section{Summary of Evidence from Eastern Europe}

The evidence we have presented for Eastern Europe is consistent with a growing body of recent evidence from the United States that similarly compares regions with changed abortion access to regions where it has been stable. We find that strict limits on abortion access are associated with large increases in the birth rate, on the order of 10 percent or more. On the basis of all available abortion numbers in these countries, we estimate that pregnancy rates fall by $27-45$ percent when abortion access is very restricted (although this is most likely an overestimate because it does not count illegal abortions). These results are somewhat larger in magnitude than estimates of the impact of abortion legalization in the United States but are consistent with earlier evidence from Romania that suggests that pregnancy rates fell about 25 percent after abortion was made illegal.

In contrast, modest restrictions on abortion access have no significant effects on birth rates but do reduce abortion rates and, by implication, pregnancy rates by a substantial amount. Our estimates indicate that modest restrictions on abortion access reduced abortions by about 25 percent and pregnancies by about 10-25 percent. Moreover, we find no evidence of a rise in maternal mortality associated with these modest restrictions, which suggests that this decline in pregnancy was not offset by any substantial rise in illegal abortions.

\section{Conclusions}

Our findings regarding the impact of changes in abortion policy on fertility outcomes in Eastern Europe are comparable to those generated for the United States in past research. In both Eastern Europe and the United States, legalizing abortion reduced the birth rate by perhaps 10 percent. In contrast, imposing modest restrictions on abortion had no impact on birth rates, despite the fact that such restrictions reduced the abortion rate in both Eastern Europe and the United States. Our evidence for Eastern Europe was drawn from a single empirical exercise comparing policy changes of differing degrees instituted over the same general time frame, while prior evidence for the United States has been pieced together from separate analyses over different time periods. The similarity in the nature of the findings in both locations strengthens our ability to draw general conclusions regarding the impact of changes in abortion policy on fertility outcomes.

Overall, this evidence is consistent with economic models in which the cost of abortion influences the decision to become pregnant as well as the decision to abort. Our evidence suggests that modest restrictions on abortion in Eastern Europe reduced abortion rates on the order of 25 percent, but also reduced pregnancy rates on the order of 10 percent with little net effect on births. Similarly, Medicaid funding restrictions and parental involvement laws in the United States have been found to reduce abortion and pregnancy rates 
with little net effect on birth rates. It is difficult to determine the impact of more severe abortion restrictions on abortions and pregnancies because of limited data on illegal abortions. Nevertheless, the positive net effect of laws making abortion illegal on the birth rate suggests that the resulting decline in abortions is larger than any decline in pregnancies. Taken together, these findings indicate that, at least in certain situations, pregnancy and abortion behavior are responsive to economic incentives.

\section{APPENDIX}

\section{DATA APPENDIX}

\section{Sources for LaW}

Childbirth by Choice Trust. Abortion in Law, History, and Religion. Toronto: Childbirth by Choice Trust, 1995.

David, Henry P., ed. From Abortion to Contraception: A Resource to Public Policies and Reproductive Behavior in Central and Eastern Europe from 1917 to the Present. Westport, Conn.: Greenwood Press, 1999.

Henshaw, Stanley K. "Induced Abortion: A World Review, 1990." Family Planning Perspectives 22 (1990): 76-89.

International Planned Parenthood Federation. Abortion Legislation in Europe. London: International Planned Parenthood Federation European Network, February 1997.

Rahman, Anika; Katzive, Laura; and Henshaw, Stanley K. "A Global Review of Laws on Induced Abortion, 1985-1997." International Family Planning Perspectives 24 (1998): 56-64.

Sachdev, Paul, ed. International Handbook on Abortion. Westport, Conn.: Greenwood Press, 1988.

Tietze, Christopher, and Henshaw, Stanley. Induced Abortion: A World Review, 1986. New York: Alan Guttmacher Institute, 1986.

United Nations. Population Division. Department of Economic and Social Affairs. Abortion Policies: A Global Review. Volume 1: Afghanistan to France. New York: United Nations, 1992.

United Nations. Population Division. Department of Economic and Social Affairs. Abortion Policies: A Global Review. Volume 2: Gabon to Norway. New York: United Nations, 1994.

United Nations. Population Division. Department of Economic and Social Affairs. Abortion Policies: A Global Review. Volume 3: Oman to Zimbabwe. New York: United Nations, 1995.

United Nations. Population Division. Department of Economic and Social Affairs. World Abortion Policies 1999. New York: United Nations, 1999.

\section{SOURCES OF DATA}

Council of Europe. Recent Demographic Developments in Europe, 1998. Belgium: Council of Europe Publishing, September 1998.

David, Henry P., ed. From Abortion to Contraception: A Resource to Public Policies and Reproductive Behavior in Central and Eastern Europe from 1917 to the Present. Westport, Conn.: Greenwood Press, 1999.

Herausgegeban von der Staatlichen Zentralverwaltung für Statistik. Statistishes Jahrbuch der Deutschen Demokratischen Republik. Berlin: Staatsverlag der Deutschen Demokratischen Republik, various years. 
Ministere de L'Economie et des Finances. Annuaire Statistique de la France. Paris: Republique Francaise, various years.

Statistisches Bundesamt. Statistishes Jahrbuch für die Bundesrepublik Deutschland. Mainz: Verlag W. Kohlhammer, various years.

Český Statistický Úrad. Statistická Ročenka České Republiky, various years.

United Nations. Department of Economic and Social Affairs. Statistics Division. Demographic Yearbook: Historical Supplement, 1948-1997. CD-ROM. New York: United Nations, 2000.

World Bank. World Development Indicators, 1999. CD-ROM. Washington, D.C.: World Bank Publications, 1999.

\section{BIBLIOGRAPHY}

Becker, Gary S. A Treatise on the Family. Cambridge, Mass.: Harvard University Press, 1981.

Bertrand, Marianne; Duflo, Esther; and Mullainathan, Sendhil. "How Much Should We Trust Difference-in-Difference Estimates?" Working paper. Cambridge: Massachusetts Institute of Technology, Department of Economics, October 2001.

Besley, Timothy, and Case, Anne. "Unnatural Experiments? Estimating the Incidence of Endogenous Policies." Economic Journal 110 (2000): F672-F694.

Blank, Rebecca M. "What Causes Public Assistance Caseloads to Grow?" Journal of Human Resources 36 (2001): 85-118.

Cartoof, Virginia G., and Klerman, Lorraine V. "Parental Consent for Abortion: Impact of the Massachusetts Law." American Journal of Public Health 76 (1986): 397-400.

Coelen, Stephen P., and McIntyre, Robert J. "An Econometric Model of Pronatalist and Abortion Policies." Journal of Political Economy 86 (1978): 1077-1101.

Cook, Philip J.; Parnell, Allan M.; Moore, Michael J.; and Pagnini, Deanna. "The Effects of Short-Term Variation in Abortion Funding on Pregnancy Outcomes." Journal of Health Economics 18 (1999): 241-58.

Currie, Janet; Nixon, Lucia; and Cole, Nancy. "Restrictions on Medicaid Funding of Abortion: Effects on Pregnancy Resolutions and Birth Weight." Journal of Human Resources 31 (1996): 159-88.

Dow, William H., and Ronan, Nick. "Maternal Mortality Effects of Abortion Legalization.” Unpublished manuscript. Santa Monica, Calif.: Rand Corporation, March 1997.

Frejka, Tomas. "Induced Abortion and Fertility: A Quarter Century of Experience in Eastern Europe." Population and Development Review 9 (1983): 494-520.

Haas-Wilson, Deborah. "The Impact of State Abortion Restrictions on Minors' Demand for Abortions." Journal of Human Resources 31 (1996): 140-58. 
Henshaw, Stanley K. "Induced Abortion: A World Review, 1990." Family Planning Perspectives 22 (1990): 76-89.

Hotz, V. Joseph, and Miller, Robert A. "An Empirical Analysis of Lifecycle Fertility and Labor Supply.” Econometrica 56 (1988): 91-118.

Joyce, Theodore. "The Impact of Induced Abortion on Black and White Birth Outcomes in the United States." Demography 24 (1987): 229-44.

Joyce, Theodore, and Kaestner, Robert. "State Reproductive Policies and Adolescent Pregnancy Resolution: The Case of Parental Involvement Laws." Journal of Health Economics 15 (1996): 579-607.

Kane, Thomas, and Staiger, Douglas. "Teen Motherhood and Abortion Access." Quarterly Journal of Economics 111 (1996): 467-506.

Levine, Phillip B. "Parental Involvement Laws and Fertility Behavior." Journal of Health Economics 22 (2003): 861-78.

Levine, Phillip B., and Staiger, Douglas. "Abortion as Insurance.” Working Paper No. 8813. Cambridge, Mass.: National Bureau of Economic Research, March 2002.

Levine, Phillip B.; Staiger, Douglas; Kane, Thomas J.; and Zimmerman, David J. "Roe v. Wade and American Fertility." American Journal of Public Health 89 (1999): 199-203.

Levine, Phillip B.; Trainor, Amy B.; and Zimmerman, David J. "The Effects of Medicaid Abortion Funding Restrictions on Abortions, Pregnancies, and Births." Journal of Health Economics 15 (1996): 555-78.

Matthews, Stephen; Ribar, David; and Wilhelm, Mark. "The Effects of Economic Conditions and Access to Reproductive Health Services on State Abortion and Birthrates." Family Planning Perspectives 29 (1996): 52-60.

O'Connell, Martin, and Rogers, Carolyn C. "Out-of-Wedlock Births, Premarital Pregnancies and Their Effect on Family Formation and Dissolution." Family Planning Perspectives 16 (1984): 157-62.

Potts, Malcolm; Diggory, Peter; and Peel, John. Abortion. New York: Cambridge University Press, 1977.

Rahman, Anika; Katzive, Laura; and Henshaw, Stanley K. "A Global Review of Laws on Induced Abortion." International Family Planning Perspectives 24 (1998): 56-64.

World Health Organization. WHO Mortality Database. Geneva, Switzerland: World Health Organization. 